\title{
Emergy assessment of tilapia cage farming in a hydroelectric reservoir
}

\author{
F. Garcia ${ }^{\mathrm{a}, *}$, J.M. Kimpara ${ }^{\mathrm{b}}$, W.C. Valenti ${ }^{\mathrm{c}}$, L.A. Ambrosio ${ }^{\mathrm{d}}$ \\ a São Paulo Agency of Agribusiness Technology - Government of the State of São Paulo, Postal Box 61, 15500-970 Votuporanga, São Paulo, Brazil

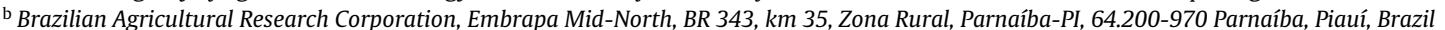 \\ ' Sao Paulo State University, Praça Infante Dom Henrique, s/n, Parque Bitaru, 11330-900 São Vicente, São Paulo, Brazil \\ d São Paulo Agency of Agribusiness Technology - Government of the State of São Paulo, Postal Box 60, 13460-000 Nova Odessa, São Paulo, Brazil
}

\section{A R T I C L E I N F O}

\section{Article history:}

Received 9 September 2013

Received in revised form 28 February 2014

Accepted 31 March 2014

Available online 25 April 2014

\section{Keywords:}

Oreochromis niloticus

Sustainability

Public policies

Stocking density

\begin{abstract}
A B S T R A C T
Considering that most of the energy supply in Brazil is derived from hydroelectric sources, the government has been strongly encouraging cage farming in federal water bodies. The government limited the aquaculture parks in hydroelectric reservoir to only $1 \%$ of its total area and, inside the parks, a ratio of 1:8 referring to the park and organic load dilution area. However, no objective evaluations proved that limit is suitable, and the absence of a methodology to evaluate this impact is a considerable problem. The aim of this study was to evaluate the Nile tilapia cage farming sustainability in a hydroelectric reservoir in Brazil using an emergy assessment and to simulate management techniques and public policies that contribute to the sustainability of this farming system. The results of the emergy assessment indicate that this production model has low renewability, is inefficient (mostly due to feeding), does not use local resources and presents high environmental impact. Therefore, we have analyzed three scenarios, in which reducing the inputs of non-renewable resources and enhancing environmental inputs were considered. Reducing the stocking density from 100 to $20 \mathrm{~kg} / \mathrm{m}^{3}$ in the initial farming stage and enhancing the dilution area from $1: 8$ to $1: 100$, referring to the cage and organic load dilution area, makes the current production system a sustainable model based on the use of natural renewable resources.
\end{abstract}

(C) 2014 Elsevier B.V. All rights reserved.

\section{Introduction}

Tilapia is the second most cultured fish in the world after carps. The total tilapia production accounted for 3,957,843 $\mathrm{t}$ in 2011 (FAO, 2013), and the production continues to grow. Tilapia's popularity is due to its hardiness and omnivorous feeding characteristics, which makes it suitable for farming under less optimal environmental conditions (Rojas and Wadsworth, 2007). Seventy-two percent of tilapia production is in Asia, particularly in China and Southeast Asia, 19\% is in Africa and 9\% is in America (FAO, 2012). Tilapia is farmed both in ponds and cages in semi-intensive and intensive systems. In recent years, cage farming has been spread all over the world because it features a relatively lower investment requirement compared to ponds and raceways (Rojas and Wadsworth, 2007), is quick and easy to start up and enables more production cycles (Baliao and Dosado, 2011).

In Brazil, $82 \%$ of the total fish production is derived from continental aquaculture, with tilapia representing the most farmed

\footnotetext{
* Corresponding author. Tel.: +55 173422 2296; fax: +55 1734222423.

E-mail addresses: fgarcia@apta.sp.gov.br, fgzoo2003@yahoo.com.br (F. Garcia).
}

aquatic species. The production of tilapia was $155,450 \mathrm{t}$ in 2010 , which corresponded to over 39\% of the total fish production (MPA, 2010). Brazil has a huge potential for aquaculture due to its water availability, and the Brazilian government has encouraged aquaculture development, as indicated by the recent creation of the Ministry of Fisheries and Aquaculture.

In a number of countries similar to Brazil, most of the energy supply is derived from hydroelectric sources; thus, there is a huge potential to establish fish cage-culture systems in reservoirs. Brazil alone has over 6.5 million ha of reservoirs, lakes and dams, with a potential capacity to produce $700,000 \mathrm{t}$ of tilapia annually (Rojas and Wadsworth, 2007). Considering this scenario, the Brazilian government has been strongly encouraging cage farming in federal water bodies. Since 2004, the Brazilian government has delimited six reservoirs totaling 28,503 hectares of water, in which 42 aquaculture parks have been installed (BRASIL, 2011). The Ministry established policies for aquaculture occupation in reservoirs to avoid adverse environmental impact and ensure multiple water use, which corresponded to limiting aquaculture parks in hydroelectric reservoir to $1 \%$ of its total area and, inside parks, a ratio of $1: 8$ referring to cage and organic load dilution area is required (BRASIL, 2004). 
Tilapia cage farming in Brazil can be considered as a relatively new production system. This production model emerged in the first decade of the $21 \mathrm{st}$ century. Most cages are $6-18 \mathrm{~m}^{3}$, in which the most cultured species is Nile tilapia, Oreochromis niloticus. Tilapia feeds exclusively on a commercial extruded diet, which is produced by large factories, and each fish spends five to seven months to reach $800 \mathrm{~g}$, at which point they are harvested and sold to be processed into skinless, boneless filets. The usual stocking density adopted in Brazil is $100 \mathrm{~kg}$ of fish per $\mathrm{m}^{3}$, while in other countries, the densities range from 2 to $50 \mathrm{~kg} / \mathrm{m}^{3}$ (Gibtan et al., 2008; Ouattara et al., 2003; Watanabe et al., 1992; Chakraborty et al., 2010).

Despite the environmental concerns presented by the regulations, no objective evaluations have been performed to determine whether this limit is suitable (David et al., 2011) to ensure sustainable fish production in reservoirs. Fish farming is not only constrained by economic factors and site-specific characteristics; it may also become constrained by a reduced or over used capacity of ecosystems to produce inputs (Zhao et al., 2013). Therefore, evaluations must be performed to guide the establishment of regulations. To reconcile conflicts between economic development and environmental protection, a science-based evaluation system known as emergy considers both values within a common measure. Emergy regards both the work of nature and that of humans in generating products and services and is a measure of the available energy of one type used up in transformations directly and indirectly to produce a service or product (Odum, 1996). Emergy analysis is a type of embodied energy analysis that provides common units (solar emergy joules [sej]) for the comparison of environmental and economic goods by summing the energy of one type required directly or indirectly for the production of goods (Odum, 1988). Thus, all inputs (from nature and economy) used in a production system are put together in a common basis: solar energy. Therefore, it is possible to interpret quantitative results from the calculated emergy indices that relate the emergy flows of the system being evaluated with those of the environment and larger economy within which it is embedded (Brown and Ulgiati, 2004).

In this context, the goals of this study were (1) to evaluate the first stage of Nile tilapia cage farming sustainability in a hydroelectric reservoir in Brazil using emergy assessment and (2) to simulate management techniques and public policies that contribute to the sustainability of this farming system.

\section{Method}

\subsection{Characteristics of the studied area}

The data used in this study were obtained from a fish farm located in the Ilha Solteira Reservoir on the Paraná River in the state of São Paulo, Brazil ( $\left.20^{\circ} 12^{\prime} 10^{\prime \prime} \mathrm{S}, 50^{\circ} 58^{\prime} 31.15^{\prime \prime} \mathrm{W}\right)$. This farm has a total of 100 cages. Each cage measures $6 \mathrm{~m}^{3}(2 \mathrm{~m} \times 2 \mathrm{~m} \times 1.5 \mathrm{~m})$. The Ilha Solteira reservoir has 49,200 ha of water, with depths ranging from 0 (at the border) to $326 \mathrm{~m}$ (at the hydroelectric dam). The surrounding area is comprised mainly of pastures used for the production of beef and dairy cattle.

During the process of delimitation of aquaculture parks by the government, streams appropriate for cage farming were defined across studies on hydrology and hydrometrics parameters, geotechnology, geomorphology, ichthyofauna, socio-economy and fisheries biology. Due to insufficient data on the carrying capacity of reservoirs and complexity to determine its value, the government determined that the size of the aquaculture parks could not exceed $1 \%$ of the reservoir. The government mandated that inside
Table 1

Indices and ratios used for evaluating tilapia cage farming in the present work (Odum, 1996).

Renewability (\%)
Emergy yield ratio
Environmental loading ratio
$\% R=100 *(R / Y)$ $(\mathrm{EYR})=\mathrm{Y} / \mathrm{F}$ $(E L R)=(N+F) / R$ $(\mathrm{ESI})=\mathrm{EYR} / \mathrm{ELR}$

each aquaculture park must be an organic load dilution area of $1: 8$ (BRASIL, 2004).

Sex-reversed Nile tilapia fingerlings (1-2g) were purchased in a hatchery located in Paraná State, which is $450 \mathrm{~km}$ far from the farm. Tilapia cage farming consists of two stages: in stage I, 420 juveniles $\left(40 \mathrm{~g}\right.$ ) per $\mathrm{m}^{3}$ are stocked until they reach $250 \mathrm{~g}$, when they are selected and redistributed among the stage II cages at a stocking density of 130 fish per $\mathrm{m}^{3}$. In both stages, the final stocking density is $100 \mathrm{~kg} / \mathrm{m}^{3}$. Fish farming management involves the removal of dead and dying fish in the morning and feeding with a commercial diet twice a day (8:00 am and 4:00 pm) following the manufacturer's recommendations. Fish from 50 to $250 \mathrm{~g}$ are fed a $2.5-\mathrm{mm}$ diet (dry matter: $88 \%$; digestible energy: $3800 \mathrm{kcal} / \mathrm{kg}$; crude protein: $42 \%$; lipids: $9 \%$ ) and those from 250 to $800 \mathrm{~g}$ are fed a 5-mm diet (dry matter: $88 \%$; digestible energy: $3500 \mathrm{kcal} / \mathrm{kg}$; crude protein: $32 \%$; lipids: $7 \%$ ). The commercial diet is produced more than $200 \mathrm{~km}$ from the fish farm. Depending on the season (water temperature) and stocking density, each tilapia requires five to seven months to reach $800 \mathrm{~g}$. After harvesting, the fish are sold to a cold storage plant. Frozen tilapia filets are sold in large markets in Brazil, and fresh filets are exported, mainly to the USA, depending on market conditions. In this study, data of the stage I of a summer productive cycle was considered, which started on October and finished on March, because in their young age, tilapias can take more advantage of natural food - phytoplankton and periphyton (renewable resources). In stage I, this feeding habit allows changes on the current productive model to improve the entry of these renewable resources in place of non-renewable sources, mainly commercial diet and the fuel to transport it.

\subsection{Emergy assessment}

In an emergy assessment, the comparison of several products is possible by considering all energy inputs on a common basis: solar energy. Emergy analysis considers the quality of each form of energy by multiplying each energy quantity by its solar transformity, which is defined as solar emergy by unit of energy (sej/J) (Odum, 1988). This methodology classifies the emergy aggregated fluxes into inputs from nature (I), formed by renewable (R) and nonrenewable resources from nature $(N),(I=R+N)$, feedbacks from the economy $(F)$, formed by materials $(M)$ and services $(S)(F=M+S)$ and the total emergy used $(\mathrm{Y}=\mathrm{I}+\mathrm{F})$. Based on these concepts, Odum (1996) proposed emergy indices and ratios to evaluate systems, which were used in the present work (Table 1).

Fig. 1 displays the diagram of tilapia cage farming based on the emergy systems language described by Odum (1996). The unit of emergy evaluation was the production of one cage, although data from all cages in the farm was used in the analysis. To determine the values of renewable environmental inputs (sun, wind, rain and spring water), we considered that each cage $\left(4 \mathrm{~m}^{2}\right.$ of surface) occupies $3200 \mathrm{~m}^{2}$ of area according to the Brazilian law, which allows aquaculture parks to occupy $1 \%$ of the superficial area of reservoirs and with a dilution area of $1: 8$. The renewable environmental inputs considered were the ones with major importance on fish farming, which were previously reported in other fish farming studies, such as Zhang et al. (2011) and Vassallo 


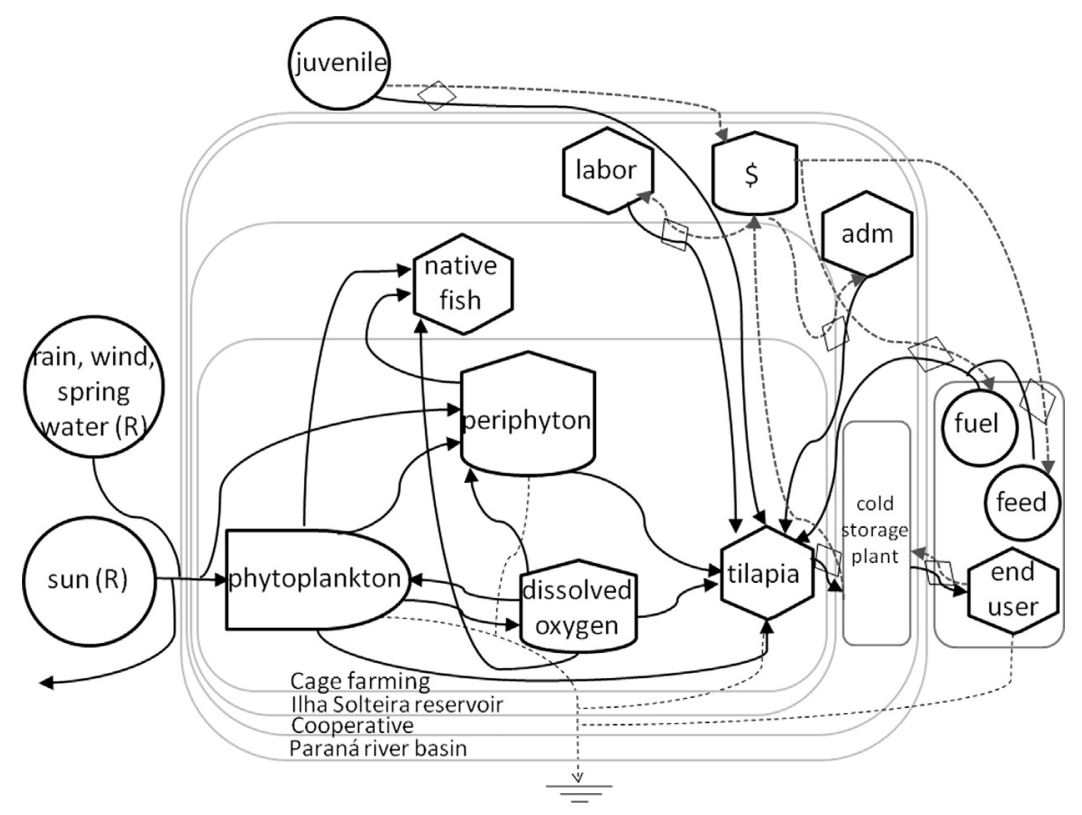

Fig. 1. Diagram of tilapia cage farming in a hydroelectric reservoir.

et al. (2007, 2009). The purchased resources were those considered by Garcia et al. (2013). The transformities employed used in this study include the labor and services required to produce economic goods.

Water was considered as a renewable input based on previous studies by Mallasen et al. (2012), who demonstrated a low degree of influence from cage farming on nutrient accumulation, including phosphorus and nitrogen, in the Ilha Solteira reservoir water. Note that this is a premise to consider water as a renewable environmental input.

Simulations were performed to assess the performance of the emergy indices and ratios using alternative management strategies. For such simulations, three scenarios were designed (Table 2) for stage I of tilapia cage farming (fish from 1 to $250 \mathrm{~g})$ :

(1) Reducing the stocking density from $100 \mathrm{~kg} / \mathrm{m}^{3}$ (D100) to $20 \mathrm{~kg} / \mathrm{m}^{3}$ (D20).

(2) Modifying the dilution area from 1:8 ( $\mathrm{HO}$ - high occupation) to 1:100 (LO - low occupation).

(3) Linking the previous scenarios.

The performance parameters used in these scenarios were obtained in Garcia et al. (2013), which evaluated tilapia stocking densities in the same reservoir.

\section{Results and discussion}

\subsection{Emergy analysis and simulations to improve sustainability of the system}

To produce tilapia in one cage, $1.09 \mathrm{E}+17 \mathrm{sej}$ are required. From this total quantity, $98.91 \%$ are materials from the economy and only $1.09 \%$ of the emergy required is from renewable sources (Table 3 ).

Transformity, which is the amount of solar energy needed to produce one unit of a product, evaluates the efficiency of a system and the quality of the energy flux, thereby allowing comparisons with other systems using other forms of energy. The transformity obtained in this study is within the range found for the carnivorous marine species of Sparus aurata and Salmo salar (Vassallo et al., 2007, 2009; Odum, 2001) (Table 4). Previous studies (Vassallo et al., 2007) suggest that if the same farming system is considered for comparison, high quality carnivorous fish, such as the salmon $S$. salar, would have higher transformity values (Odum, 2001) than omnivorous fish, such as tilapia (Brown et al., 1992). The results of the present study demonstrate the inefficiency of the current tilapia cage farming model evaluated in Brazil, in which feeding accounts for over $70 \%$ of the total emergy flux (Table 3 ). This productive model is more similar to farming systems involving carnivorous species than the systems involving filter feeding species used in many countries.

Table 2

Characteristics, performance parameters (based on Garcia et al., 2013) and scenarios of Nile tilapia cage farming analyzed.

\begin{tabular}{|c|c|c|c|c|}
\hline & \multirow{2}{*}{$\begin{array}{l}\text { Usual Brazilian system } \\
\text { D100 }-\mathrm{HO}^{\mathrm{c}}\end{array}$} & \multicolumn{3}{|l|}{ Scenarios } \\
\hline & & $\mathrm{D} 20^{\mathrm{b}}-\mathrm{HO}^{\mathrm{c}}$ & $\mathrm{D} 100^{\mathrm{a}}-\mathrm{LO}^{\mathrm{d}}$ & $\mathrm{D} 20^{\mathrm{b}}-\mathrm{LO}^{\mathrm{d}}$ \\
\hline Stocking density $\left(\mathrm{kg} / \mathrm{m}^{3}\right)$ & 100 & 20 & 100 & 20 \\
\hline Daily weight gain $(\mathrm{g})$ & 3.73 & 7.00 & 3.73 & 7.00 \\
\hline Feed conversion rate & 1.35 & 0.65 & 1.35 & 0.65 \\
\hline Proportion of dilution area (cage area: dilution area) & $1: 8$ & $1: 8$ & $1: 100$ & $1: 100$ \\
\hline
\end{tabular}

a D100 - stocking density of $100 \mathrm{~kg} / \mathrm{m}^{3}$.

b D20 - stocking density of $20 \mathrm{~kg} / \mathrm{m}^{3}$.

c $\mathrm{HO}$ - high occupation.

d LO - low occupation. 
Table 3

Emergy evaluation of the Brazilian Nile tilapia cage-farming.

\begin{tabular}{|c|c|c|c|c|c|c|c|c|c|}
\hline Item & Unit & $\begin{array}{l}\text { Unit } \\
\text { ha/year }\end{array}$ & $\begin{array}{l}\text { Unit } \\
\text { cage/year }\end{array}$ & $\begin{array}{l}\text { Transformity } \\
\text { sej/unit }\end{array}$ & $\begin{array}{l}\text { Renewable } \\
\text { emergy } \\
\text { flux }\end{array}$ & $\begin{array}{l}\text { Non- } \\
\text { renewable } \\
\text { emergy } \\
\text { flux }\end{array}$ & $\begin{array}{l}\text { Total } \\
\text { emergy } \\
\text { flux }\end{array}$ & $\%$ & References \\
\hline \multicolumn{10}{|l|}{ Natural resources $(\mathrm{I})$} \\
\hline \multicolumn{10}{|l|}{ Renewable $(\mathbf{R})$} \\
\hline Sun & $\mathrm{J}$ & $4.32 \mathrm{E}+13$ & $1.38 \mathrm{E}+13$ & $1.00 \mathrm{E}+00$ & $1.38 \mathrm{E}+13$ & & $1.38 \mathrm{E}+13$ & 0.01 & Odum et al. (2000) \\
\hline Wind & $\mathrm{J}$ & $1.3 \mathrm{E}+11$ & $4.16 \mathrm{E}+10$ & $2.45 \mathrm{E}+03$ & $1.02 \mathrm{E}+14$ & & $1.02 \mathrm{E}+14$ & 0.09 & Odum et al. (2000) \\
\hline Rain & $\mathrm{J}$ & $7.95 \mathrm{E}+10$ & $2.54 \mathrm{E}+10$ & $4.70 \mathrm{E}+04$ & $1.20 \mathrm{E}+15$ & & $1.20 \mathrm{E}+15$ & 1.09 & Odum et al. (2000) \\
\hline Spring water & $\mathrm{J}$ & $3.60 \mathrm{E}+08$ & $1.15 \mathrm{E}+08$ & $1.66 \mathrm{E}+05$ & $1.91 \mathrm{E}+13$ & & $1.91 \mathrm{E}+13$ & 0.02 & Buenfil (2001) \\
\hline $\begin{array}{l}\text { Total (maximum } \\
\text { among the above } \\
\text { items) }\end{array}$ & & & & & & & $1.20 \mathrm{E}+15$ & 1.09 & \\
\hline \multicolumn{10}{|c|}{ Feedbacks from Economy (F) } \\
\hline \multicolumn{10}{|c|}{ Materials (M) } \\
\hline Boat & US\$ & & $1.66 \mathrm{E}+01$ & $3.70 \mathrm{E}+12$ & & $6.15 \mathrm{E}+13$ & $6.15 \mathrm{E}+13$ & 0.06 & Ortega (1998) \\
\hline Cages & US\$ & & $5.55 \mathrm{E}+01$ & $3.70 \mathrm{E}+12$ & & $2.05 \mathrm{E}+14$ & $2.05 \mathrm{E}+14$ & 0.19 & Ortega (1998) \\
\hline Outboard engine $15 \mathrm{HP}$ & US\$ & & $3.28 \mathrm{E}+01$ & $3.70 \mathrm{E}+12$ & & $1.21 \mathrm{E}+14$ & $1.21 \mathrm{E}+14$ & 0.11 & Ortega (1998) \\
\hline Barge & US\$ & & $4.34 \mathrm{E}+01$ & $3.70 \mathrm{E}+12$ & & $1.61 \mathrm{E}+14$ & $1.61 \mathrm{E}+14$ & 0.15 & Ortega (1998) \\
\hline Pier & US\$ & & $1.28 \mathrm{E}+01$ & $3.70 \mathrm{E}+12$ & & $4.73 E+13$ & $4.73 \mathrm{E}+13$ & 0.04 & Ortega (1998) \\
\hline "Anchor remover" & US\$ & & $1.34 \mathrm{E}+01$ & $3.70 \mathrm{E}+12$ & & $4.97 \mathrm{E}+13$ & $4.97 \mathrm{E}+13$ & 0.05 & Ortega (1998) \\
\hline Compressor & US\$ & & $1.13 \mathrm{E}+01$ & $3.70 \mathrm{E}+12$ & & $4.20 \mathrm{E}+13$ & $4.20 \mathrm{E}+13$ & 0.04 & Ortega (1998) \\
\hline Scale & US\$ & & $1.36 \mathrm{E}+01$ & $3.70 \mathrm{E}+12$ & & $5.03 \mathrm{E}+13$ & $5.03 \mathrm{E}+13$ & 0.05 & Ortega (1998) \\
\hline Feed storage building & US\$ & & $4.99 \mathrm{E}+01$ & $3.70 \mathrm{E}+12$ & & $1.85 \mathrm{E}+14$ & $1.85 \mathrm{E}+14$ & 0.17 & Ortega (1998) \\
\hline Other equipments & US\$ & & $2.82 \mathrm{E}+01$ & $3.70 \mathrm{E}+12$ & & $1.04 \mathrm{E}+14$ & $1.04 \mathrm{E}+14$ & 0.10 & Ortega (1998) \\
\hline Juveniles & US\$ & & $5.29 \mathrm{E}+03$ & $3.70 \mathrm{E}+12$ & & $1.96 \mathrm{E}+16$ & $1.96 \mathrm{E}+16$ & 17.85 & Ortega (1998) \\
\hline Feed & $\mathrm{J}$ & & $8.37 \mathrm{E}+10$ & $1.00 \mathrm{E}+06$ & & $8.37 \mathrm{E}+16$ & $8.37 \mathrm{E}+16$ & 76.43 & Odum (2001) \\
\hline Boat fuel $^{\mathrm{a}}$ & $\mathrm{J}$ & & $4.56 \mathrm{E}+08$ & $5.30 \mathrm{E}+04$ & & $2.42 \mathrm{E}+13$ & $2.42 \mathrm{E}+13$ & 0.02 & Odum (1996) \\
\hline Fuel for feed transport ${ }^{\mathrm{b}}$ & $\mathrm{J}$ & & $1.86 \mathrm{E}+10$ & $5.30 \mathrm{E}+04$ & & $9.83 \mathrm{E}+14$ & $9.83 \mathrm{E}+14$ & 0.90 & $\begin{array}{l}\text { Brown and Bardi } \\
(2001 a, b)\end{array}$ \\
\hline Juveniles & $\mathrm{J}$ & & $4.97 \mathrm{E}+07$ & $3.36 \mathrm{E}+05$ & & $1.67 \mathrm{E}+13$ & $1.67 \mathrm{E}+13$ & 0.02 & $\begin{array}{l}\text { Brown and Ulgiati } \\
\text { (2004) }\end{array}$ \\
\hline \multicolumn{10}{|l|}{ Services (S) } \\
\hline Skilled labor ${ }^{c}$ & US\$ & & $1.85 \mathrm{E}+02$ & $3.70 \mathrm{E}+12$ & & $6.83 \mathrm{E}+14$ & $6.83 \mathrm{E}+14$ & 0.62 & Ortega (1998) \\
\hline Laborer $^{\mathrm{d}}$ & US\$ & & $1.39 \mathrm{E}+02$ & $3.70 \mathrm{E}+12$ & & $5.14 \mathrm{E}+14$ & $5.14 \mathrm{E}+14$ & 0.47 & Ortega (1998) \\
\hline Day laborer ${ }^{\mathrm{e}}$ & US\$ & & $4.56 \mathrm{E}+02$ & $3.70 \mathrm{E}+12$ & & $1.69 \mathrm{E}+15$ & $1.69 \mathrm{E}+15$ & 1.54 & Ortega (1998) \\
\hline Total emergy (Y) & & & $1.84 \mathrm{E}+12$ & & $1.20 \mathrm{E}+15$ & $1.08 \mathrm{E}+17$ & $1.09 \mathrm{E}+17$ & 100 & \\
\hline \multicolumn{10}{|l|}{ Product energy (Ep) } \\
\hline Tilapia & $\mathrm{J}$ & & $8.09 E+10$ & & & & & & \\
\hline
\end{tabular}

Notes: All transformities and specific emergies are relative to the $9.26 \mathrm{E}+24 \mathrm{sej} / \mathrm{y}$ planetary baseline (Campbell, 2000).

a Gasoline and oil used in the boat (to feed fish, to move cages, to remove dead fish, etc.).

b Diesel oil used in the trucks to transport diet from the feed manufacturers to the fish farm.

c Manager of fish farm.

d People involved in farming.

e The worker paid on a per day basis that renders services on a non-continuous basis.

Table 4

Comparison of emergy indexes evaluating different fish farming systems and species.

\begin{tabular}{llcc}
\hline & Transformity & ELR & EYR \\
\hline $\begin{array}{l}\text { Sparus aurata, marine } \\
\text { inshore farm, autumn } \\
\text { stock (Vassallo et al., }\end{array}$ & $9.92 \mathrm{E}+5$ & 4.65 & 1.23 \\
$\begin{array}{c}\text { 2009) } \\
\text { Sparus aurata, marine } \\
\text { inshore farm, spring } \\
\text { stock (Vassallo et al., }\end{array}$ & $5.50 \mathrm{E}+5$ & 3.65 & 1.28 \\
$\quad \begin{array}{l}\text { 2009) } \\
\text { S. aurata, marine inshore } \\
\text { farm (Vassallo et al., }\end{array}$ & $1.32 \mathrm{E}+6$ & & \\
$\quad \begin{array}{l}\text { 2007) } \\
\text { Salmo salar, pen culture } \\
\quad \text { Odum, 2001) }\end{array}$ & $9.70 \mathrm{E}+6$ & 5.00 & 1.20 \\
$\begin{array}{c}\text { O. niloticus, cage (present } \\
\text { study) }\end{array}$ & $1.35 \mathrm{E}+6$ & 4.24 & 1.23 \\
\hline
\end{tabular}

Current tilapia cage farming is highly dependent on nonrenewable resources and is inefficient (Table 3). Renewability is a way to measure the sustainability or autonomy of a system. In the long run, only processes with high renewability are sustainable (Brown and Ulgiati, 2004) because such systems are more likely to be successful in economic competition when non-renewable resources are limited (Lefoy and Rydberg, 2003). The partial renewability of $1.09 \%$ found in the present study is much lower than rates reported by Vassallo et al. (2009, 2007), in which renewability rates ranged from $17 \%$ to $22 \%$, depending on the season, in a marine fish farm of gilthead sea bream (S. aurata) in La Spezia Gulf, Italy; Bastianoni (2002) reported a rate of $75 \%$ in a semi-natural extensive fish farming system and Odum (2001) reported a rate of $19 \%$ in an intensive salmon farming system.

The high dependence on economic resources is represented in the emergy yield ratio (EYR), which indicates the amount of energy from nature that the process returns to the economic sector. An EYR close to 1 , as in the present study, demonstrates that the system consumes as much emergy as it makes available to the economy. A higher ratio denotes greater capacity to incorporate contributions from nature and lower dependence on economic resources. In the present study, the EYR was 1.01, which is the lowest of all systems presented in Table 4 . This result demonstrates that the productive model works more like an industrial process than an agricultural process, in which animals feed on local photosynthesis products.

The environmental loading ratio (ELR) of tilapia cage farming was evaluated to determine the impact of the productive system on the ecosystem. A higher ELR denotes a greater impact from an economic system on the natural environment. An ELR greater than 10 , as found in the present study, indicates high environmental 
impact due to the high non-renewable emergy fluxes concentrated in a small area of the local ecosystem. The ELR determined in the present study indicates that an aquaculture park occupying $1 \%$ of the reservoir with a dilution area of 1:8 (as allowed by law) results in a high environmental impact. Reducing this proportion would be beneficial for the system because fewer resources from the economy are used and more natural resources are available to "dilute" the environmental impact with a larger area of the reservoir. Even the most intensive systems (Vassallo et al., 2007, 2009; Odum, 2001 ) presented in Table 4 have a much lower ELR in comparison to the value in the present study due to the higher contribution of renewable resources in those systems, i.e., high tidal amplitude at the Oregon coast, where salmon cage farming is installed.

A higher emergy sustainability index (ESI) denotes a more sustainable system (Brown and Ulgiati, 1997). When used to compare processes yielding the same product, values greater than 1 are indicative of products that have net contributions to society (Brown and Ulgiati, 1997). An ESI lower than 1 indicates a system that consumes resources and indicates a well-developed system oriented toward consumption, such as the one examined in this study (Table 5). The current tilapia farming model does not have a desirable sustainability index. The cage production system is a recent development in Brazil that was established by pioneering fish farmers. Due to the hardness of the chosen species (Nile tilapia) and the good water quality in hydroelectric reservoirs, farmers have used the maximum stocking density supported by the system to enhance productivity. However, studies have shown that a high stocking density limits fish growth and requires the use of more feed for the development of fish, thereby increasing production costs and reducing profits (Garcia et al., 2013; Ayroza et al., 2011). Moreover, a system operating at its limit capacity runs a high risk environmental and sanitary collapse (Garcia et al., 2013). Previous studies indicate that a reduction in the stocking density leads to better individual weight gain and water quality, with a consequent reduction in the production costs, improvement in the uniformity of fish size and a reduction in the occurrence of bacteria and parasites (Garcia et al., 2013). In this context, adjustments should be made in current tilapia cage farming model. Attempts must be made to reduce the input of non-renewable resources and increase the participation of renewable resources. Because diet accounts for the highest percentage of the emergy flux and has a low degree of renewability, new strategies to reduce feed supply should be investigated. A scenario was simulated in which the stocking density in stage I was reduced from $100 \mathrm{~kg} / \mathrm{m}^{3}$ to $20 \mathrm{~kg} / \mathrm{m}^{3}$ (D20 - HO) to increase the efficiency of the system and reduce the feed conversion rate (amount of feed necessary to produce $1 \mathrm{~kg}$ of fish) (Table 5). However, the results of this simulation (D20 - HO) demonstrate that this reduction was insufficient to ensure the sustainability of the system, as the indices improved only slightly (Table 5). Moreover, resources from nature $(R)$ continued to be much less expressive than resources from the economy (F) (Fig. 2).

A second scenario was subsequently designed in which the real stocking density was used and the dilution area was improved from 1:8 to $1: 100$ (D100 - LO). While the results demonstrate an improvement in the indicators (Table 5), the second scenario was still not able to achieve sustainable patterns. In this scenario, the ELR underwent the most significant improvement, reaching values close to those reported by Odum (2001) in S. salar farming. In this scenario, the contribution of renewable natural resources (R) was increased but remained lower than the contribution of resources from the economy (F) (Fig. 2).

To enhance the evaluated indices and propose a real sustainable productive model, we designed a third scenario. In this scenario, both scenarios previously presented were used. In other words, the stocking density was reduced to $20 \mathrm{~kg} / \mathrm{m}^{3}$ and the dilution area was

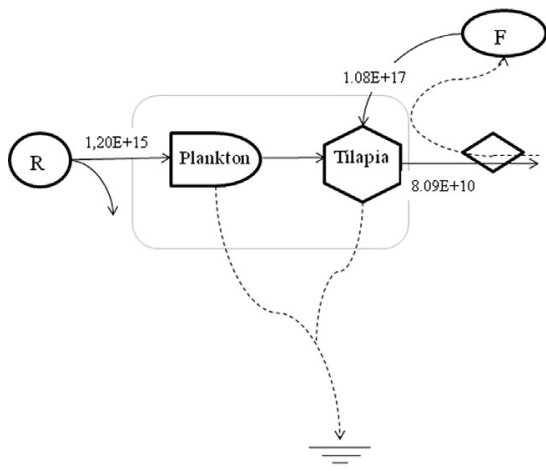

$\mathrm{D} 10 \mathrm{O}-\mathrm{HO}$

$\mathrm{D} 2 \mathrm{O}-\mathrm{HO}$

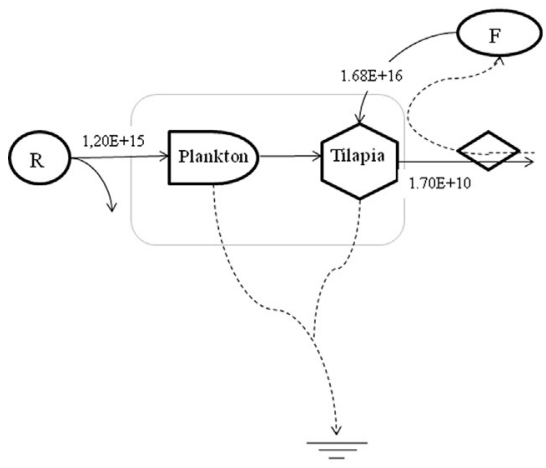

D100 - LO

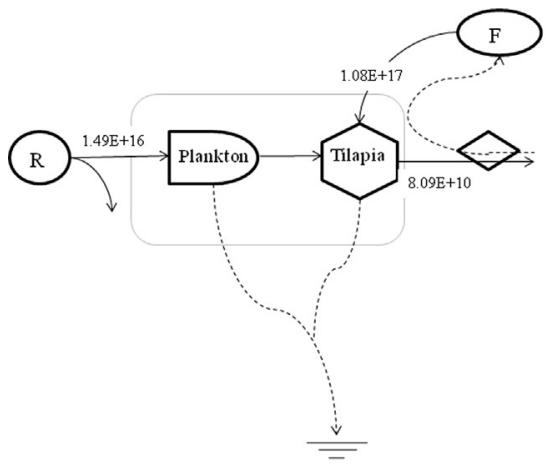

D2O - LO

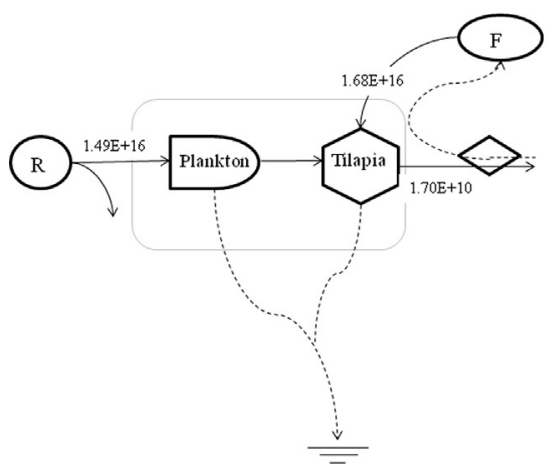

Fig. 2. Diagrams summarizing the emergy fluxes in Nile tilapia cage farming at stocking densities of $100 \mathrm{~kg} / \mathrm{m}^{3}$ (D100) and $20 \mathrm{~kg} / \mathrm{m}^{3}$ (D20) with the proportion of cage area in relation to dilution area of 1:8 (HO - high occupation) and 1:100 (LO low occupation). 
Table 5

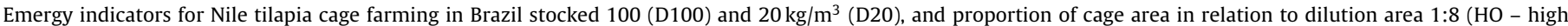
occupation) and 1:100 (LO - low occupation) of the area designated to fish farming.

\begin{tabular}{|c|c|c|c|c|}
\hline \multirow[t]{2}{*}{ Emergy indexes } & \multirow{2}{*}{$\begin{array}{l}\text { Usual Brazilian system } \\
\text { D100 - HO }\end{array}$} & \multicolumn{3}{|l|}{ Scenarios } \\
\hline & & $\mathrm{D} 20-\mathrm{HO}$ & D100 - LO & D20 - LO \\
\hline Transformity & $1.35 \mathrm{E}+06$ & $1.05 \mathrm{E}+06$ & $1.52 \mathrm{E}+06$ & $1.86 \mathrm{E}+06$ \\
\hline Renewability (\%Ren) & 1.09 & 6.66 & 12.14 & 47.14 \\
\hline Emergy yield ratio (EYR) & 1.01 & 1.07 & 1.14 & 1.89 \\
\hline Environmental loading ratio (ELR) & 90.51 & 14.02 & 7.24 & 1.12 \\
\hline Emergy sustainability index (ESI) & 90.51 & 14.02 & 7.24 & 1.12 \\
\hline
\end{tabular}

improved from 1:8 (HO - high occupation) to 1:100 (LO - low occupation). After these modifications, all the indices were improved and reached desirable values for a sustainable production system (Table 5). The contribution of renewable resources from nature $(R)$ was close to the contribution of resources from economy (F) (Fig. 2).

Fig. 3 shows the total water area from the reservoir and a detail of the site where the fish farm is installed, with the current demarcated area of 100 cages for the fish farm (dilution area 1:8) and the simulated delimitation if the dilution area was increased to 1:100. Even with this increase in area, the availability of water for other aquaculture enterprises is huge. In combination with the reduction in the stocking density, the increase in the area should ensure the sustainability of the production of Nile tilapia cage farms.

\subsection{Area required to supply resources for ensuring the maintenance of the activities}

To ensure the maintenance of the fish farming activity, it is necessary to provide renewable resources to feed the system and to determine whether the area designated for the activity is sufficiently large to absorb the impact generated (Fig. 4). The ELR demonstrates that adjustments are required to alleviate the pressure caused in the ecosystem. With regard to the supply of resources, it is essential to ensure the quantity and quality of inlet water in the reservoir. In 2006, 53\% of the environmental impact in the Ilha Solteira reservoir corresponded to the siltation and 33\% was related to erosive processes (Pereira, 2006). The estimated period until the total siltation of the Itaipú, Itá, Sobradinho and Tucuruí reservoirs in Brazil is greater than 1000 years. Within a shorter period (20-30 years), however, sand deposits in the backwater will affect navigation activities and favor the growth of macrophytes at the edges of the reservoirs, where cage farming activities are installed. Cage farming depends on a particular water depth to maintain water circulation for a sufficient amount of dissolved oxygen for the fish and the removal of fish droppings, leftover feed and toxic compounds from decomposition processes.

Solid sediment discharge by area may be as much as $12 \mathrm{~kg}$ per hectare per day compromising both water availability and quality

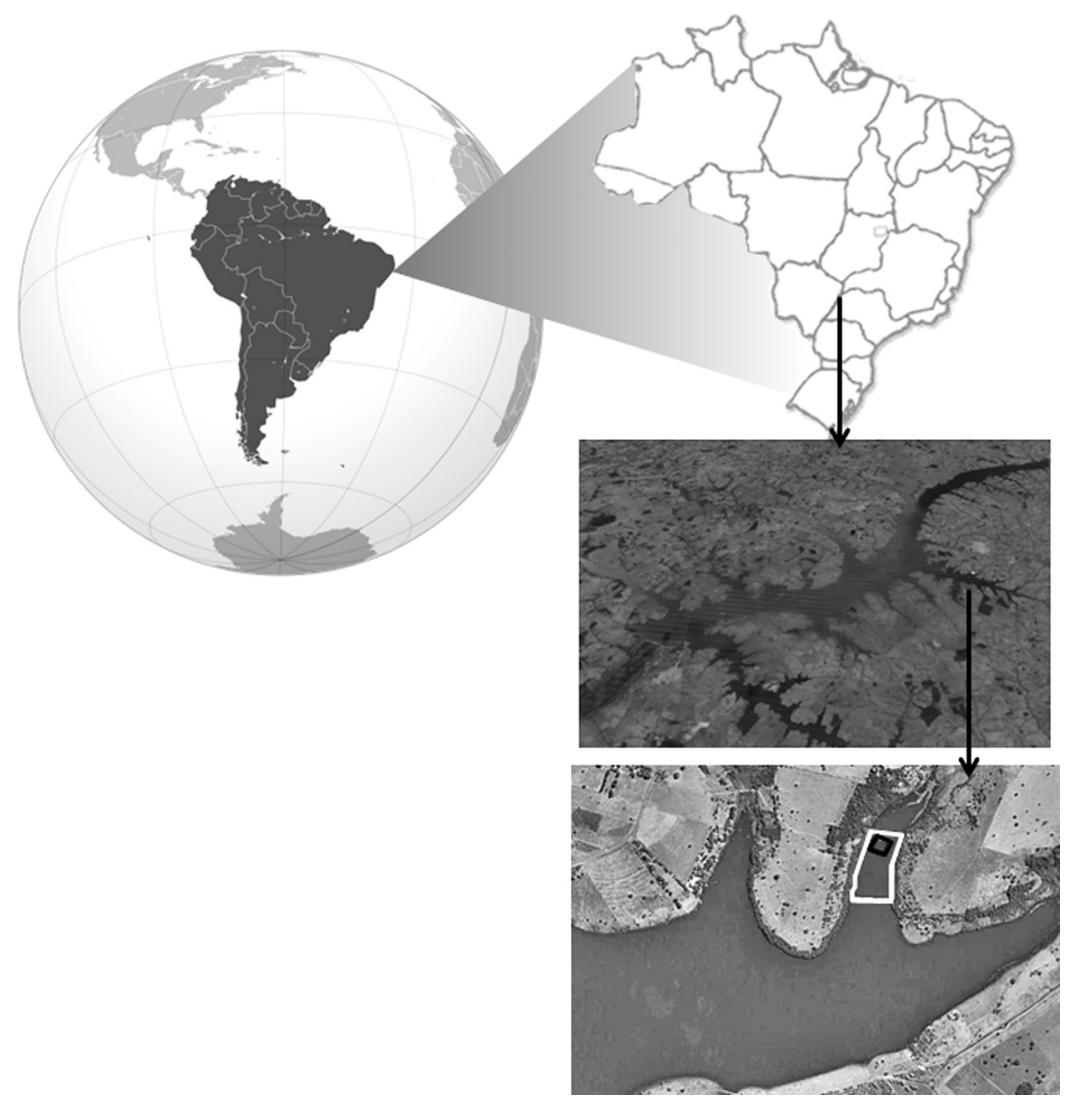

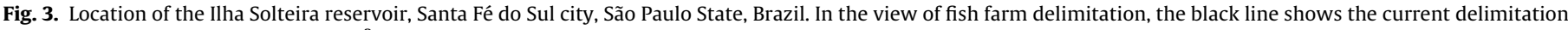

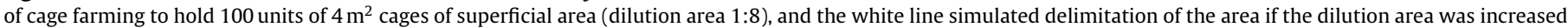
to $1: 100$. 
Table 6

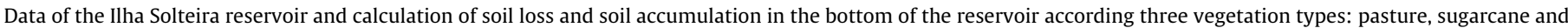
annual crops.

\begin{tabular}{|c|c|c|c|c|c|c|c|c|c|}
\hline Vegetation & $\begin{array}{l}\text { Soil lossa } \\
\text { (t/ha/year) }\end{array}$ & $\begin{array}{l}\text { Flooded } \\
\text { area }^{\mathrm{a}}\left(\mathrm{km}^{2}\right)\end{array}$ & $\begin{array}{l}\text { Maximum } \\
\text { volume of } \\
\text { the } \\
\text { reservoir } \\
\left(\mathrm{m}^{3}\right)\end{array}$ & $\begin{array}{l}\text { Reservoir } \\
\text { catchment } \\
\text { area }^{\mathrm{a}} \text { (ha) }\end{array}$ & $\begin{array}{l}\text { High area } \\
\left(\mathrm{km}^{2}\right)\end{array}$ & $\begin{array}{l}\text { Average } \\
\text { depth }^{\mathrm{a}}(\mathrm{m})\end{array}$ & $\begin{array}{l}\text { Soil loss in } \\
\text { high area } \\
\text { (t/ha/year) }\end{array}$ & $\begin{array}{l}\text { Soil accu- } \\
\text { mulation in } \\
\text { the bottom } \\
\text { of the } \\
\text { reservoir } \\
\left(\mathrm{m}^{3} / \text { year) }\right.\end{array}$ & $\begin{array}{l}\text { Soil accu- } \\
\text { mulation in } \\
\text { the bottom } \\
\text { of the } \\
\text { reservoir } \\
\text { (cm/year) }\end{array}$ \\
\hline Pasture & 0.4 & 1195 & $21,060 \mathrm{E}+6$ & $9,949,631$ & 375,460 & 17 & $150,184 \mathrm{E}+2$ & $1,155,262$ & 0.10 \\
\hline Sugarcane & 12.4 & 1195 & $21,060 \mathrm{E}+6$ & $9,949,631$ & 375,460 & 17 & $4,655,704 \mathrm{E}+2$ & $35,813,108$ & 3.00 \\
\hline Annual crops & 24.5 & 1195 & $21,060 \mathrm{E}+6$ & $9,949,631$ & 375,460 & 17 & $919,877 \mathrm{E}+3$ & $70,759,769$ & 5.92 \\
\hline
\end{tabular}

a Source: Pereira (2006).

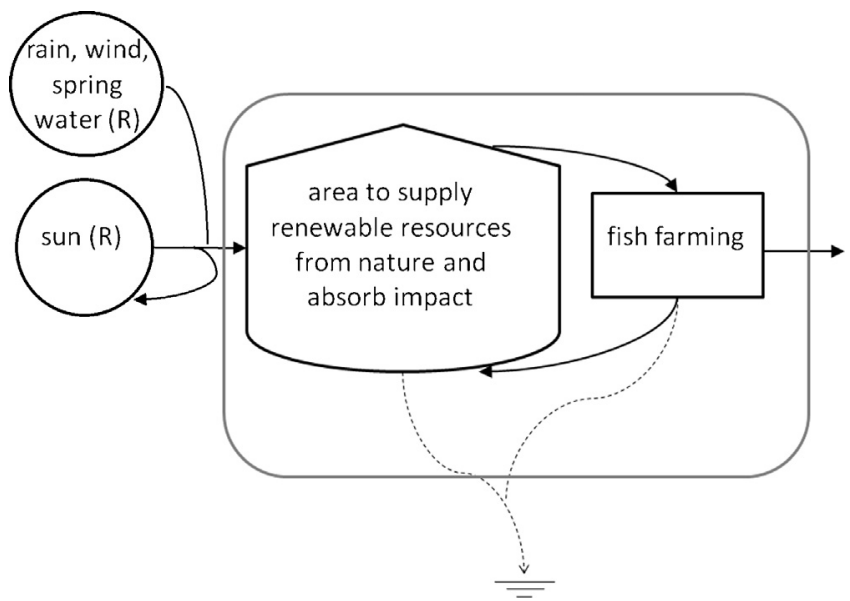

Fig. 4. Diagram showing the areas of natural resources supply and the environmental impact absorption related to tilapia cage farming in a hydroelectric reservoir.

(Hernandez and Vanzela, 2007). Soil loss varies according to vegetation cover, area slope, soil conservation techniques, etc. (Pereira, 2006) and riparian vegetation have the important function of filtering the sediment, nutrients and pollutants from agricultural areas (Sparovek et al., 2001; Nieminen et al., 2005; Cavalcanti and Lockaby, 2006). Currently, in Ilha Solteira reservoir, only $0.67 \%$ of the natural vegetation surrounding the reservoir remains (Pereira, 2006), even for the panorama of the several rivers of the state of São Paulo, such as the Tietê, Grande, Paranapanema, Paraíba do Sul and Paraná rivers (Noffs et al., 2000). To determine the real potential of siltation of the Ilha Solteira reservoir, soil loss and mean sediment accumulation on the bottom of the reservoir were estimated based on the mean values on land use presented by the authors cited (Table 6). Three land use scenarios were considered: grazing pasture, sugarcane plantations and annual crops. As $87.09 \%$ of the area surrounding the reservoir is covered by pastures (Pereira, 2006), the first scenario considered the entire ground clearance area around the reservoir to be covered by pastures. In this scenario, the soil loss was estimated at 15,018,400 t/ha/year, with a mean ground clearance of $1 \mathrm{~mm}$ per year if equally distributed throughout the entire flooded area. The second scenario considered gradually replacing pastures with sugarcane plantations (Pereira, 2006). Thus, if the total ground clearance were covered by sugarcane, $3 \mathrm{~cm}$ of soil per year would accumulate in the flooded area. The third scenario considered an accumulation of $5.92 \mathrm{~cm}$ of soil per year at the bottom of the reservoir if the entire area were used for annual crops (Table 6).

Regarding this finding, to ensure the supply of renewable resources to feed the cage farming system in hydroelectric reservoirs, compliance of the current environmental legislation is essential (BRASIL, 2012a,b), which determines the formation of an area of permanent environmental protection bordering the bodies of water. The width determined for this area is $30 \mathrm{~m}$ and $100 \mathrm{~m}$ in reservoirs located in urban and rural environments, respectively. According to current legislation, hydroelectric plants are responsible for reforestation and monitoring of the areas bordering the reservoir and face state and federal fines and penalties for the irregular use and occupation of land.

\section{Conclusions}

(1) Despite being considered an omnivorous, filter-feeding species, the Nile tilapia are raised in cages in Brazil using the production model developed for carnivorous fish species, which has high energy costs regarding the use of resources from the economy. The system will be strongly affected or even extinct if nonrenewable resources become scarce. To reduce the input of resources from the economy, especially feed, and increase the use of renewable natural resources (i.e., plankton), the feeding efficiency of productive process would be enhanced by reducing the stocking density from 100 to $20 \mathrm{~kg} / \mathrm{m}^{3}$ in the initial phase. This stocking density reduction will reduce the feed conversion rate and the inputs from the economy. However, the reduction in the stocking density would not lower the extremely high environmental loading ratio in the current system, which indicates a high environmental impact concentrated in a very small area. Therefore, the current limit of area occupation by cages in aquaculture parks should be increased to ensure a sufficient area to supply renewable resources and absorb the impact. From the emergy standpoint, a sustainable model based on the use of renewable natural resources requires increasing the dilution area to a size that is 100 -fold the cage area instead of using a dilution area only 8-fold larger than the cage area, as established by current legislation, and reducing the stocking density from 100 to $20 \mathrm{~kg} / \mathrm{m}^{3}$.

(2) To ensure the supply of renewable natural resources in fish farming, we demonstrated the need to recover riparian vegetation in the Ilha Solteira reservoir. The responsible hydroelectric power station must determine if the riparian recovery cost would be more costly than letting the power station become useless due to soil accumulation in the dam over a relatively short period. For auditing institutions, the incumbency of ensuring compliance of the laws is important. For fish farmers, fishers, local community and civil society, actions to provide incentives and to request the rights of water use warranty are important.

(3) One of the noble roles of local government is to provide incentives for food production while ensuring the sustainability of systems. In the case of aquaculture in large reservoirs, the challenge is to establish limits that ensure multiple water uses and the success of the activity over a long period of time. Emergy analysis is an efficient tool for evaluating and leading systems 
toward desirable practices to achieve sustainability. Therefore, future studies similar to this one may facilitate the process of decision making and public policy formulation toward a sustainable aquaculture.

\section{Acknowledgments}

This study has been funded by the Fundação de Amparo à Pesquisa de São Paulo, Process 2010/50154-6. We thank Prof. Dr. Enrique Ortega for the valuable suggestions.

\section{References}

Ayroza, L.M.S., Romagosa, E., Ayroza, D.M.M.R., Scorvo Filho, J.D., Salles, F.A., 2011. Custos e rentabilidade da produção de juvenis de tilápia-do-nilo em tanquesrede utilizando-se diferentes densidades de estocagem. Rev. Bras. Zootecn. 40, 231-239.

Baliao, D.D., Dosado, N.S., 2011. Tilapia cage farming in freshwater reservoir using artificial diets during dry and wet seasons. Philipp. Agric. Scientist 94, 38-45.

Bastianoni, S., 2002. Use of thermodynamic orientors to assess the efficiency of ecosystems: a case study in the Lagoon of Venice. Sci. World J. 2, 255-260.

Brown, M.T., BARDI, E., 2001a. Handbook of Emergy Evaluation. Folio \#3. University of Florida Press.

Brown, M.T., Green, P., Gonzalez, A., Venegas, J., 1992. Emergy Analysis Perspectives, Public Policy Options, and Development Guidelines for the Coastal Zone of Nayarit, Mexico. Report to The Cousteau Society and the Government of Nayarit, Mexico. Vol. 1: Coastal Zone Management Plan and Development Guidelines. Center for Wetlands and Water Resources, University of Florida, Gainesville, $392 \mathrm{pp}$.

Brown, M.T., Ulgiati, S., 1997. Emergy-based indices and ratios to evaluate sustainability: monitoring economies and technology toward environmentally sound innovation. Ecol. Eng. 9, 51-69.

Brown, M.T., Bardi, E., 2001b. Handbook of Emergy Evaluation. Folio 3: Emergy of Ecosystems. Center for Environmental Policy, University of Florida, Gainesville.

Brown, M.T., Ulgiati, S., 2004. Emergy analysis and environmental accounting. Encyclop. Energy 2, 329-354.

Buenfil, A.A., 2001. Emergy Evaluation of Water. Dissertation Presented to the Graduate School of the University of Florida, $264 \mathrm{pp}$.

Campbell, D.E., 2000. A revised solar transformity for tidal energy received by the earth and dissipated globally: implications for emergy analysis. In: Brown, M.T., Brandt-Williams, S., Tilley, D., Ulgiati, S. (Eds.), Emergy Synthesis. 1. Theory and Applications of the Emergy Methodology. Center for Environmental Policy, University of Florida, Gainesville, pp. 255-264.

Cavalcanti, G.G., Lockaby, B.G., 2006. Effects of sediment deposition on aboveground net primary productivity, vegetation composition and structure in riparian forests. Wetlands 26, 400-409.

Chakraborty, S.B., Mazumdar, D., Banerjee, S., 2010. Determination of ideal stocking density for cage culture of monosex Nile tilapia (Oreochromis niloticus) in India. Proc. Zool. Soc. 63, 53-59.

David, G.S., Carvalho, E.D., Ramos, I.P., Silva, R.J., Silveira, A.N., Yasumaru, F., Ribeiro, C.C., Lemos, D., 2011. Load models support sustainable planning for Brazil's reservoir aquaculture. Global Aquac. Advoc., 23-25.

FAO, 2012. The State of World Fisheries and Aquaculture. FAO, Rome, 230 pp.

Garcia, F., Romera, D.M., Gozi, K.S., Onaka, E.M., Fonseca, F.S., Schalch, S.H.C., Candeira, P.G., Guerra, L.O., Carmo, F.J., Carneiro, D.J., Martins, M.I.E., Portella, M.C., 2013. Stocking density of Nile tilapia in cages placed in a hydroelectric reservoir. Aquaculture 410-411, 51-56.

Gibtan, A., Getahun, A., Mengistou, S., 2008. Effect of stocking density on the growth performance and yield of Nile tilapia [Oreochromis niloticus (L. 1758)] in a cage culture system in Lake Kuriftu, Ethiopia. Aquac. Res. 39, $1450-1460$.

Hernandez, F.B.T., Vanzela, L.S., 2007. Transporte de sedimento na microbacia do córrego Três Barras, Marinópolis, SP. In: Proceedings of Congresso Brasileiro de Engenharia Agrícola, p. 36.

Lefoy, E., Rydberg, T., 2003. Emergy evaluation of three cropping systems in southwestern Australia. Ecol. Modell. 161, 195-211.
Mallasen, M., Carmo, C.F., Tucci, A., Barros, H.P., Rojas, N.E.T., Fonseca, F.S., Yamashita, E.Y., 2012. Qualidade da Água em Sistema de Piscicultura em Tanques-rede no Reservatório de Ilha Solteira, SP. Bol. Inst. Pesca 38, 15-30.

Nieminen, M., Ahti, E., Nousianen, S.J., Voullekoski, M., 2005. Capacity of riparian buffer zones to reduce sediment concentrations in discharge from peatlands drained for forest. Silva Fenn. 39, 331-339.

Noffs, P.S., Galli, L.F., Gonçalves, J.C., 2000. Recuperação de áreas degradadas da Mata Atlântica - uma experiência da CESP, second ed. MMA, 48 pp.

Odum, H.T., 1996. Environmental Accounting - Emergy and Environmental Decision Making. John Wiley \& Sons, Inc., USA, 370 pp.

Odum, H.T., 1988. Self-organization, transformity, and information. Science 242, $1132-1139$.

Odum, H.T., Brown, M.T., Brandt-Williams, S., 2000. Handbook of Emergy Evaluation: A Compendium of Data for Emergy Computation Issued in a Series of Folios. Folio \#1. Introduction and Global Budget. University of Florida, Gainesville, 17 pp.

Odum, H.T., 2001. Emergy Evaluation of Salmon Pen Culture. University of Florida Press.

Ouattara, N.I., Teugels, G.G., Douba, V.N., Philippart, J.C., 2003. Aquaculture potential of the black-chinned tilapia, Sarotherodon melanotheron (Cichlidae). Comparative study of the effect of stocking density on growth performance of landlocked and natural populations under cage culture conditions in Lake Ayame (Côte d'Ivoire). Aquac. Res. 34, 1223-1229 (Short Communication).

Pereira, A.O., 2006. Caracterização do uso e ocupação do solo na área de influência do reservatório de Ilha Solteira. Dissertation presented to the Programa Recursos Hídricos e Tecnologias Ambientais of University of São Paulo State, 95 pp.

Rojas, A., Wadsworth, S., 2007. A review of cage culture: Latin America and the Caribbean. In: Halwart, M., Soto, D., Arthur, J.R. (Eds.), Cage Aquaculture Regional Reviews and Global Overview. FAO Technical Paper 498. FAO, Rome, $259 \mathrm{pp}$.

Sparovek, G., Ranieri, S.B.L., Gassner, A., de Maria, I.C., Schnug, E., Santos, R.F., Joubert, A., 2001. A conceptual framework for the definition of the optimal width of riparian forests. Agric. Ecosyst. Environ. 90, 169-175.

Vassallo, P., Bastianoni, S., Beiso, I., Ridolfi, R., Fabiano, M., 2007. Emergy analysis for the environmental sustainability of an inshore fish farming system. Ecol. Indic. 7, 290-298.

Vassallo, P., Beiso, I., Bastianoni, S., Fabiano, M., 2009. Dynamic emergy evaluation of a fish farm rearing process. J. Environ. Manage. 90, 2699-2708.

Watanabe, W.O., Clarck, J.H., Dunham, J.B., Wicklund, R.I., Olla, B.L., 1992. Culture of Florida red tilapia in marine cages: the effect of stocking density and dietary protein on growth. In: 42 Proceedings of the Forty-Four Annual Gulf and Caribbean Fisheries Institute, Charleston, SC, USA, pp. 449-454.

Zhang, L.X., Ulgiati, S., Yang, Z.F., Chen, B., 2011. Emergy evaluation and economic analysis of three wetland fish farming systems in Nansi Lake area, China. J. Environ. Manage. 92, 683-694

Zhao, S., Song, K., Gui, F., Cai, H., Jin, W., Wu, C., 2013. The emergy ecological footprint for small fish farm in China. Ecol. Indic. 29, 62-67.

Web references

BRASIL, 2004. Instrução Normativa Interministerial $\mathrm{n}^{\circ} 06$ de 31 de maio de 2004, Available from: http://www.planejamento.gov.br/secretarias/ upload/Legislacao/Instrucao_Normativa/040531_IN_inter_06.pdf

BRASIL, 2011. Ministério da Pesca e Aquicultura - Parques Aquícolas, http://www.mpa.gov.br/index.php/aquiculturampa/aguas-da-uniao/parquesaquicolas/parquesaquicolas-continentais (accessed on February 2013).

BRASIL, 2012a. Lei no. 12.651, de 25 de maio de 2012. Dispõe sobre a proteção da vegetação nativa. Diário Oficial da República Federativa do Brasil, Poder Executivo, Brasília, DF, 28 de março de 2012, Available from: https://www.planalto.gov.br/ccivil_03/_ato2011-2014/2012/lei/112651.htm

BRASIL, 2012b. Lei no 12.727, de 17 de outubro de 2012. Altera a Lei no. 12.651, de 25 de maio de 2012. Diário Oficial da República Federativa do Brasil, Poder Executivo, Brasília, DF, 18 de outubro de 2012, Available from: http://www.planalto.gov.br/ccivil_03/_Ato2011-2014/2012/Lei/L12727.htm

FAO, 2013. Global aquaculture production 1950-2011, Available from: http://www.fao.org/figis/servlet/SQServlet?file=/work/FIGIS/prod/webapps/ figis/temp/hqp_7965280663346448588.xml\&outtype=html

MPA, 2010. Ministério da Pesca e Aquicultura: Produção pesqueira e aquícola/Estatística 2008 e 2009, Available from: http://www.mpa.gov.br

Ortega, 1998. Tabela de transformidades (emergia/Joule, emergia/kg, emergia/US\$), Available from: http://www.unicamp.br/fea/ortega/curso/transformid.htm 